\title{
Exposure as Collected Elapsed Time
}

National Cancer Institute

\section{Source}

National Cancer Institute. Exposure as Collected Elapsed Time. NCI Thesaurus. Code C117503.

The interval between two collected exposure reference time points. 